\title{
THE DEVELOPMENT OF THE NEOCLASSICAL TRADITION IN LABOR ECONOMICS
}

\author{
GEORGE R . BOYER and ROBERT S. SMITH*
}

\begin{abstract}
This essay on labor economics examines neoclassical theory's rise to ascendancy following the second World War, with a secondary focus on the relative decline but continued influence of institutionalist economic theory. The authors describe the evolution of institutional and neoclassical theory from the late nineteenth to mid-twentieth centuries, examine some early intellectual debates between the two camps, briefly describe the work of neoclassical labor economics pioneers, and look at major developments over the past 30 years. They argue that neoclassical economists' increasing intellectual breadth and influence in public policy have led them to pay closer attention to issues that have long been of concern to institutionalists and "neoinstitutionalists."
\end{abstract}

$\mathrm{T}$ he field of labor economics has changed dramatically in the postwar period. At the end of the second World War, labor economics was dominated by a group of academics who, while knowledgeable of neoclassical theory, had their roots in the institutionalist approach to economics. However, the next thirty years saw the rise to dominance of an approach to labor economics that was rooted in neoclassical economic theory. The same period saw a decline, within economics departments, of institutionalist-based labor economics. The

*The authors are Professors in the Department of Labor Economics, New York State School of Industrial and Labor Relations, Cornell University. They thank John Abowd, Robert Aronson, Francine Blau, Ronald Ehrenberg, Gary Fields, Robert Hutchens, George Jakubson, Lawrence Kahn, Harry Katz, and Marcus Rebick for their perspectives on postwar labor economics and comments on various drafts of this essay. institutionalist approach survived, and in some universities continued to thrive, but its practitioners tended to move out of economics departments and into departments of industrial relations or business schools. This essay chronicles the rise to dominance of the neoclassical approach to labor economics.

We begin by describing the roots of the institutionalist and neoclassical "camps" in the half-century before the second World War. This is followed by an examination of the state of labor economics in the first postwar decade, and of some early intellectual debates between the institutional and neoclassical camps. We then briefly describe the work of four of the pioneers of neoclassical labor economics-H. Gregg Lewis, Gary Becker, Jacob Mincer, and George Stigler. Finally, we examine some of the major developments in neoclassical labor economics since the early 1970s, and show how the neoclassical has been influenced by the institutional approach. 
Our essay is an attempt to generate some insights into how economic thought about labor issues has developed and been modified over the past half century. It is not meant to be a survey of all aspects of labor economics, both neoclassical and institutional. Our focus throughout is on the development and modification of the neoclassical approach. We begin with the roots of the two alternative approaches to studying the labor market.

\section{The Historical Antecedents of Two Traditions}

During the interwar years, the entire discipline of economics was characterized by what one recent author (Yonay 1998) has termed a "struggle over the soul of economics" between two fundamentally distinct approaches toward understanding economic phenomena: neoclassical economics and institutionalism. Neoclassical economics began in the late nineteenth century as a challenge to the classical economics of David Ricardo and John Stuart Mill. It "replaced the individual economic agent as a sociological or historical datum by the utility-maximizing individual" (Stigler 1969:225). Although classical economics and neoclassical economics contained similar laissez-faire social philosophies, the issues addressed by the two schools were much different. Classical economics had focused on economic growth; neoclassical economics focused on issues of relative prices and allocation of a given set of resources. According to the English economist Joan Robinson (1953:22), classical economics had been concerned with "big questions," such as the distribution of output among wages, rent, and profits. Neoclassical economics, on the other hand, assumed that the big questions had been answered, and focused on "little questions," such as "Why does an egg cost more than a cup of tea?" This new focus on prices and their underlying supply and demand conditions permitted analytical techniques thatwere deductive and abstract, and in time this approach was to become mathematical.
Institutionalism began in the United States at about the same time that Alfred Marshall's Principles of Economics (1890) was laying the groundwork for what we now call neoclassical labor economics. Institutionalism's roots can be traced back to the German historical school of economics, and some of its founders, such as Richard Ely, had been trained in Germany (McNulty 1980:131-33; Kaufman 1993:30-31). Ely described the economics that was taught in American universities in the $1870 \mathrm{~s}$ and 1880 s as "dry bones"-focusing entirely on "natural economic laws" and laissez faire, and seeing people as simply "instruments] by which wealth is created and not the end for which it exists" (Ely 1938:125-27). Ely rejected this "barren" approach, and turned his attention to the study of practical problems (including those facing the American labor movement) using a variety of methods. ${ }^{1}$ In 1886 he published The Labor Movement in America, which, while largely a historical work, is regarded by many as the first American labor economics text.

In 1892 the University of Wisconsin hired Ely to be director of the newly formed School of Economics, Political Science, and History, and in 1904 he hired his former student at Johns Hopkins, John R. Commons, to teach labor economics. Commons "turned the University of Wisconsin in Madison into a center of institutionalist research, that is, of rigorous study of the evolution and practicing of various economic organizations" (Yonay 1998:51). In 1905, two of Commons's colleagues at Wisconsin, Thomas Adams and Helen Sumner, published a textbook entitled Labor Problems, which typified the institutionalist approach to labor economics. In the preface Adams and Sumner (1905:v) wrote that "the principal aim of this book is to furnish

'According to McNulty (1980:133), Ely's interests were "so wide ... that only a fraction of the topics on which he wrote could be said to belong to the realm of economics." As evidence of his broad interests, Ely's graduate students later became professors of sociology and history as well as economics. 
a convenient collection of facts that will facilitate the study and the teaching of the American labor problem." The book had two parts: "Evils" and "Remedies." "Evils" contained chapters on women and child labor, immigration, the sweating system, and poverty. "Remedies" included chapters on unions, profit-sharing, cooperation, industrial education, labor laws, and the material progress of the wage-earning class. In the same year Commons (1905) published a collection of recent papers by himself and others in a volume entitled Trade Unionism and Labor Problems, which complemented the Adams and Sumner text. Thus emerged what was later called "institutionalist labor economics."

Instinationalist labor economics emphasized the word labor. This approach was fact-based, its methodology largely was inductive, and it generally relied on a casestudy approach toward data-gathering. From the intensive, often historical, study of individual cases or events came detailed descriptions of various labor-market institutions or outcomes. Followers of this institutional approach differentiated "descriptive economics" from "economic theory," and saw their role as providing "data sufficiently concrete, definite, and convenient to form a basis for analysis, discussion, and criticism" (Commons 1905:iii). ${ }^{2}$ In 1926, a reviewer of Solomon Blum'sjust-published institutionalist textbook, entitled Labor Economics (which appears to be the first book with these words in its title), put institutional economics in the following context:

The economic drift has been and continues to be from the deductive to the inductive method of attack, ... from the concentration upon the logically postulated reactions of the economic man to concentration upon groups of men creating (and being variously affected by) economic institutions. In the place of the old, single, outstanding problem of the analysis of the economic man ... we now face, and have to deal with, a long series of problems each of

For a recent perspective on institutional economics, see Hodgson (1998). which concerns itself with ... an institution or a group of institutions and the consequences for men of the operation of these institutions. (Brissenden 1926)

In contrast to the institutional approach, the neoclassical approach to labor economics-which emphasizes the word econom$i c s$-is built upon posited maximizing models of firms and workers at the individual level, and it is ahistorical in nature. One starts, as did Marshall, with certain fundamental principles about economic actors, not a collection of facts, and from theoretical analyses (often expressed and reasoned mathematically) are drawn hypotheses or conclusions about labor market outcomes. In its quest for analysis, this approach looks for general patterns rather than pathologies peculiar to certain institutions or markets. Put in terms of modern statistical analysis, so widely used in testing hypotheses about the labor market, the neoclassical approach seeks to discover systematic behavioral tendencies, and it comfortably relegates deviations from these tendencies to the "unexplained variation" of the error term.

The principal strength of the neoclassical approach is that it satisfies the scholarly yearning for general principles that can organize "mere" facts, and it is the absence of general principles that was seen as a weakness of institutionalism. Ronald Coase summed up the work of institutionalists in this way: "Without a theory they had nothing to pass on except a mass of descriptive material waiting for a theory, or a fire" (cited in Posner 1993:206). The principal criticism of the theoretic approach is that, often, too little attention is given to reality-either in forming hypotheses about labor market behaviors or in testing them empirically. Again we turn to Coase, who wrote, "In my youth it was said that what was too silly to be said may be sung. In modern economics it may be put into mathematics" (cited in Posner 1993:198-99).

A neoclassical approach to labor economics appeared poised to take hold in the decade prior to World War II with the publication of two very different books by the same title: The Theory of Wages. John Hicks's 
The Theory of Wages, published in 1932, was a theoretical work with little attempt at empirical analysis. Hicks wrote that the purpose of his book was to restate "the theory of wages in a form which shall be reasonably abreast of modern economic knowledge" (1932:v), and its chapters dealt with labor demand and the theory of marginal productivity, the supply of labor, competition, and the undesirable side-effects of governmental regulation. ${ }^{3}$ His analysis of individuals' supply of labor was influenced by Lionel Robbins's important article published two years earlier, which demonstrated the conditions under which individuals' labor supply curves were positively or negatively sloped. ${ }^{4}$

In 1934, Paul Douglas came out with his Theory of Wages. Unlike Hicks, Douglas combined theoretical explication with an attempt to "determine the slopes of the demand and supply curves of the various commodities" relevant to the production process (Douglas 1934:xii) . In so doing, Douglas-who was very interested in real-world problems and public policy issues-tried to steer a middle ground between theoretical deduction and empirically based induction. In the preface he wrote, "The younger generation of economists ... are increasingly turning on the one hand from the sterile shadow-boxing which has characterized so much of dialectical economics and on the other from the theoretical blind alley of the purely historical and institutional methods" (1934:xii).

Thus, approaches that organized the subject matter of labor economics by theo-

Hicks's book also contained a model of the bargaining process between labor and management that is still taught in both labor economics and collective bargaining courses.

Prior to Robbins (1930), most economists argued that short-run labor supply curves were always negatively sloped. For example, Frank Knight (1921:11718) argued that "rational" men would always reduce their hours of work when their wage increased. Knight's justification for this conclusion is based entirely on an analysis of the income effect.

Douglas's book contained pioneering attempts to estimate labor supply elasticities. His analysis of labor supply is extended in Schoenberg and Douglas (1937). retical concepts, and that stressed general principles rather than descriptive detail, were neither unknown nor awaiting discovery in the 1930s. Yet the institutionalist approach to labor-market issues-dominant until then-continued its primacy through the first two postwar decades. Why?

One fundamental reason why a neoclassical approach to labor economics did not take hold with the publication of the Hicks and Douglas texts was the Great Depression. Unemployment rates of $25 \%$, closed banks, and bread lines focused attention of labor-market scholars away from abstraction and toward policies for the immediate amelioration of human suffering. To most, the market had clearly failed. It is little wonder, then, that market forces, in both theory and practice, were either dismissed or considered social evils to be mitigated, and that labor unions, as institutions that had become central actors in many labor markets, were accorded such preeminence in labor textbooks of the day. In the second edition to his Theory of Wages, published in 1963, Hicks himself lamented that "1932 was not a lucky date for the appearance of a book like this. It was the blackest year of the Great Depression; there has been no date in this century to which the theory that I was putting out could have been more inappropriate... So, soon after its birth, The Theory of Wages began to look like the last gasp of an ancien regime" (1963:305).

It is also noteworthy that both Hicks and Douglas published little in the field of labor economics after the mid-1930s. Hicks, whose interests shifted to economic theory, came to believe that his Theory of Wages had "fearful gaps" and let it go out of print "because my own views upon its subject had changed so much that I no longer desired to be represented by it" (Hicks 1963:v, 306) .

Hicks did, however, allow the book to be reprinted in 1963, because "it has ... been made clear to me that there is still a demand for it" (1963:v). Many modern labor economists have a high regard for The Theory of Wages. For example, Sherwin Rosen (1985:1144) refers to it as a "remarkably enduring work." 
Douglas increasingly turned his energies to public life, first as a member of the Chicago City Council (1939-42), then as an officer in the Marines, and ultimately as a United States Senator (after 1948). Thus, the field of labor economics was abandoned by the two prewar scholars who could have served best to advance a neoclassical approach.

\section{Labor Economics in the Early Postwar Period}

As noted, the neoclassical and institutionalist approaches to labor markets reflected a larger debate within the field of economics during the 1920s and 1930s over how the study of economic phenomena should be conducted. Despite their deep skepticism of neoclassical modeling, institutionalists generally regarded themselves as-and were perceived by others to beeconomists (Yonay 1998:71-76). Indeed, Douglas considered Commons to be "perhaps the most magnificent economics teacher of my time" (Douglas 1971:35), and the authors of the institutionalist labor textbooks of the 1930s-Blum (1925), Carroll Daugherty (1933), Dale Yoder (1933), and Harry Millis and Royal Montgomery (1938)-all were members of economics departments in their universities.

At a minimum, the cohabitation of institutionalists and price theorists in interwar economics departments meant that graduate students of the day who were interested in labor economics had to obtain a grounding in standard economic theory. Thus, when World War II ended, the field of labor economics was in the hands of scholars-most notably, John Dunlop, Clark Kerr, Richard Lester, and Lloyd Reynolds-who were well-versed in neoclassical theory but deeply skeptical of its relevance to the real world. In the words of Kerr,

For nascent labor economists in the early 1930 s ... the two most important recent books of special relevance were by Lionel Robbins ( $A n$ Essay on the Nature and Significance of Economic Science, 1932) and by John R. Hicks (The Theory of Wages, also 1932). They both carried discouraging messages which, if followed, would have aborted any interest in labor economics by any reasonably intelligent person. The central message of the first was that realistic studies were the low road and pure theory the high road. The central message of the second was that all that needed to be known about labor economics was already known, since it was a sub-branch of standard marginal analysis applied to nearly perfect labor markets with few special characteristics. (Kerr 1988:1)

The distinctly ambivalent attitude toward neoclassical theory of the early postwar labor economists is reflected in a textbook published in 1941 by Princeton's Lester. The book, entitled Economics of Labor, began by explaining to the reader that the text was "analytic rather than encyclopedic. The emphasis throughout the book is upon economic principles rather than upon particular events or ephemeral facts" (p. vii). Lester had by no means turned his back on the institutionalist approach, however, as can be seen by the book's organization and the titles of its three major parts: "labor's economic problems"; "organization and labor relations"; and "collective bargaining in certain industries." Moreover, Lester eschewed the very generalization that theory seeks: "Generalization is especially difficult when each problem that arises may be unique because it presents a slightly different combination of factors or a new set of circumstances" (p. 38). Carroll Daugherty, in a 1945 paper on the labor field in the American Economic Review, described the ambivalence of Lester's approach in this way:

There is, in fact, no labor textbook which satisfactorily employs and integrates the tools of economic analysis in its discussions. The best thing thus far in this respect is R. A. Lester's Economics of Labor ... and labor teachers and writers are greatly in his debt. But Lester, after berating his competitors in front of his textbook audience ... misses the trapeze in midair and is fortunate to land in the safety net of confusion, (p. 655)

Yale's Reynolds published a textbook entitled Labor Economics and Labor Relations in 1949, and it also was largely atheoretic in its approach. The book's first sentence proclaimed it to be an "introduction to the 
study of labor"—note that despite its title, it was not introduced as a study of economics. The first $60 \%$ of the book was devoted to unions (including chapters on union history, governance, and politics), and the chapters in the "economics" section mainly described practices followed by firms and industries in setting wages. Filled with descriptive narrative on unions, government regulations, and employers' practices, and sprinkled with a handful of tables and charts describing trends and conditions, the book contained virtually no analysis of how supply and demand affect the price of labor.

That Reynolds's text dominated the market for at least the next two decades is a telling indication of how labor economics was taught to students during this period. Between 1964 and 1970, however, Reynolds revised his text to place the section called "Economics of the Labor Market" first rather than second. While the fifth (1970) edition maintained its original flavor-with collective bargaining's history, law and governance, tactics, and outcomes still occupying $60 \%$ of the space-the preface noted,

In this edition, I have reversed the previous sequence and have placed the economic analysis at the beginning of the book ... First, labor economics is basic in the sense that the economics of collective bargaining is included within it ... Second, research in labor economics is shifting in a quantitative and econometric direction ... The wealth of new research material warrants both enlarging the "economic" component of this text and placing it at the beginning of the discussion. (Reynolds 1970:iv)

More than the ordering of topics, however, there was an increased emphasis on theory. In contrast to just one graph included in its original edition, fully 20 theory-related graphs could be found in the "economics" part of the book's 1970 edition-which by then had chapters on demand and supply.

The trend that by 1970 had induced a major change in Reynolds's text also gave birth to the first two thoroughly neoclassical labor economics textbooks in the postwar period: Labor Economics: Theory and Evidenceby Helton Fleisher (1970), and The Economics of Work and Pay by Albert Rees
(1973). These texts, which in many ways were quite similar, had surprisingly little in common with the textbooks of the 1940s and 1950s, or indeed even with the 1970 edition of Reynolds's textbook. ${ }^{8}$ Rees maintained in his introduction that economists trained in the "institutional tradition ... have tended to move into industrial relations ... and [become] somewhat isolated from the main stream of economics." $\mathrm{He}$ wrote that his book "does not pretend to cover industrial relations ... Rather it will concentrate on the application of economic theory and statistics to the problems of labor markets" (Rees 1973:viii).

A glance at the tables of contents shows how different the Fleisher and Rees texts were from their predecessors. Gone were the long sections on labor history, labor law, and union organization, and replacing them in both texts was a single chapter concerned only with the economic aspects of trade unions, such as formal models of union objectives and the measurement of union-nonunion wage differentials. These texts were organized by theoretical constructs, not labor issues or institutions, and each had chapters on the supply of labor by individuals, human capital investments by firms and workers, and the demand for labor in competitive and noncompetitive markets and over both the short and long

A third book, Richard Freeman's Labor Economics (1972), could also be included in this list. Freeman's book is theory-based, but it is quite short and was not intended to be a text for a full semester course in labor economics.

In 1957 Melvin Reder published a labor economics textbook that, had it met with more success, might have served as a smooth transition between the "neoinstitutionalists" and the neoclassicists. The text began, as did Reynolds's, with a lengthy section on unions, but its economics section was of a very different flavor. As opposed to the skepticism about neoclassical theory of the neoinstitutionalists, Reder was fascinated with theory and took pains to both examine critical assumptions and point out where behavior was-or could be seen as-consistent with theory. The market for labor economics texts was clearly not ready for such a book, and it did not survive into a second edition. 
run. Both books were so devoid of descriptive material that neither was as long as 300 pages (Reynolds's book was by now running nearly 700 pages).

The change made in Reynolds's text and the appearance of two theory-based competitors suggest that the market for the neoclassical approach had grown to a critical size by the early 1970s. Further, since textbooks tend to follow intellectual trends, not lead them, their change in basic approach by the early 1970s suggests that during the 1950s and 1960s some very important groundwork had been laid toward a new and very different way to conceptualize labor economics. The next sections investigate various aspects of how this change came about.

\section{Early Postwar Labor Economists: The End of One Line or the Continuation of Another?}

Viewed retrospectively, did the work of the early postwar labor economists serve as a link between Hicks/Douglas in the early 1930s and the neoclassical labor economists whose theory-oriented analyses began to shape the field a generation later? Put somewhat differently, can the early postwar labor economists best be characterized as institutionalists who knew economic theory ("neoinstinationalists"), or as neoclassical economists with "realistic" interests?

Most likely because of their training, their academic departments, and the perceived obsolescence of "institutionalism," the early postwar labor economists have tended to see themselves as being in the latter campas "neoclassical revisionists" striving to use the realism of the earlier institutionalists to enrich standard price theory as Hicks had applied it to the labor market. Kerr, for example, says that "members of the revisionist group had been trained in the theory of the thirties-in Hicks, in Robinson and Chamberlain, and in Keynes ... They did not reject theory, as did the institutionalists ... rather, they respected theory and wanted to make it more useful in understanding practice" (Kerr 1988:13).
While Kerr admitted that the "revisionists" focused their attention on the realism and applicability of standard theory rather than suggest postulates that would extend its explanatory power (Kerr 1988:2-3), he would later claim that the revisionists achieved their greatest victory in 1963 when Hicks (in the second edition of The Theory of Wages) acknowledged that social forces play an essential role, notjust a marginal one, in the labor market (Kerr 1994:68). A close inspection of Hicks's 1963 book, however, reveals that it contains no mention whatever of any of the "realistic studies" by the revisionists. Moreover, the seminal works by the earliest of the neoclassical labor economists (to be discussed later), which were being published with regularity by the 1960 s, made virtually no reference to the works of the early postwar scholars. It is therefore very difficult to argue that the latter were "revisionists" in the same evolutionary chain as the founders of modern labor economics - and relatively easy to accept labeling them as "neoinstitutionalists." 9

The early postwar scholars were all energetic, trained in economics, academically respected, and persuasive enough to take on leadership roles of one sort or another in academic or government circles. Why, then, do they appear more like an extension of the "institutionalist" line than, as they might have hoped, a vehicle for extending neoclassical theory? Inquiring into the reasons for their failure to serve as a bridge between the institutional and neoclassical schools leads us to a consideration of intellectual controversies that illustrate both the two alternative approaches and the compelling attraction of a neoclassical framework for viewing the labor market. We start with a controversy that arose quite explicitly in the 1940s.

\footnotetext{
${ }^{9}$ The term "neoinstitutionalists" was coined by Cain (1976). Kerr has called the terminology "inaccurate, even misleading" (1988:13). He coined the term "neoclassical revisionists" to refer to economists such as Dunlop, Reynolds, Lester, and himself.
} 


\section{Debate on the Marginal Productivity Theory of Demand}

The concept underlying the theory of labor demand by firms is the notion that adding workers while holding capital constant increases output. These increments to output ("marginal productivity") are assumed to diminish, however, as more and more labor is added, and a profit-maximizing firm is posited to stop hiring when the value of labor's marginal product falls below the cost of hiring this extra labor. Thus, theory implies that when a wage increase causes the costs of hiring labor to rise, firms will cut their use of labor in order to bring the value of marginal productivity back in line with marginal labor costs. The concept of diminishing marginal productivity and the chain of reasoning underlying the postulated profit-seeking behavior of firms are what underlie the downward-sloping labor demand curve so central to neoclassical theory.

In an article published in 1946, Richard Lester took issue with the relevance of this theory of labor demand. His interviews with business executives (note the case study approach) led him to conclude that these decision-makers neither thought in terms of marginal productivity nor, as a practical matter, could explicitly calculate labor's marginal product with any degree of confidence. He therefore concluded that "much of the economic reasoning on company employment adjustments to increases or decreases in wage rates is invalid, and a new theory of wage-employment relationships for the individual firm must be developed" (Lester 1946:71). In essence, Lester doubted the relevance of the marginal productivity theory of labor demand and asserted that its irrelevance was caused by simplistic or invalid deductive modeling. ${ }^{10}$

\footnotetext{
'"Lester's criticism of the marginal productivity theory of labor demand was similar in some ways to earlier criticisms made by Paul Douglas in The Theory of Wages. However, Douglas concluded that "the forces upon which the productivity school built their theories are ... powerful. To the extent that they are operative, the conclusions which are drawn from
}

Professor Fritz Machlup, then at the University of Buffalo, sprang to the defense of neoclassical theory by arguing that Lester misunderstood the role of theoretical models in analyzing behavior. Machlup argued that a driver of a car deciding whether to overtake a truck proceeding slowly in front of him on a two-lane road will not explicitly measure or calculate in a formal way all the variables involved in making a decision about overtaking the vehicle. However, if scientists were to model and predict this driver's behavior, they would have to formally adopt and numerically solve such a model. Machlup argued that

the explanation of an action must often include steps of reasoning which the acting individual himself does not consciously perform (because the action has become routine) and which perhaps he would never be able to perform in scientific exactness (because such exactness is not necessary in everyday life). To call, on these grounds, the theory "invalid," "unrealistic" or "inapplicable" is to reveal failure to understand the basic methodological constitution of most social sciences. (Machlup 1946:535)

Machlup's arguments carried the day, and even the neoinstitutionalist texts that succeeded Lester's continued to analyze the demand for labor in terms of the marginal productivity model. Still, the neoinstitutionalists maintained their deep misgivings about price theory's lack of realism.

\section{The Role of Theory in "Realistic" Studies}

As quotations from Kerr and Lester have made clear, the early postwar labor economists felt that standard economic theory inadequately represented the complexity of observed phenomena. Further, they seemed to believe that if they could bring to

them are valid, and the results are modified but not vitiated by the presence of other forces which are at work as well" (1934:95). He adds in a footnote, "The critics of the marginal productivity theory have frequently betrayed their ignorance of the nature of scientific law. The law of gravitation, for example, had not been rendered invalid by the development of heavier than air airplanes" (p. 95). 
light "realistic" evidence that was inconsistent with economic theory, then others in the economics profession would be motivated to change standard theory as applied to the labor market. A case in point was a 1948 article on money wage movements by Reynolds in the American Economic Review, which called for economists to be more attentive to empirical reality in their modelbuilding. This article, like those of the other neoinstitutionalists, did not attempt to construct a new theory or modify an existing one to account for apparent empirical inconsistencies. A neoclassical economist reading such an article could be forgiven for concluding that the author himself saw little to be gained in molding standard theory to fit labor-market facts.

What the neoinstitutionalists failed to understand or acknowledge about paradigm changes was stated by Paul Samuelson in a 1951 paper on wage theory: "In economics it takes a theory to kill a theory; facts can only dent the theorist's hide" (Samuelson 1951a:323). Samuelson's implicit view of the centrality of theory to social analyses was elaborated more explicitly in 1953 by Milton Friedman. While neoinstitutionalists were inclined to think and write about the enormous complexity of labor markets, Friedman argued that the whole purpose of theoretical models is to strip away complexity so that fundamental tendencies can be more clearly seen.

Models, Friedman argued, should notbe judged by the "realism" of their assumptions (as the neoinstitutionalists were wont to do), because critical behaviors necessarily must be simplified by assumption if prediction is to become possible in a complex world. Instead, he argued forjudging theories by the quality of their predictions. Echoing Machlup, Friedman argued that if a theory predicts behavioral tendencies often enough to find support in the data, then it is useful even if its underlying assumptions do not always and everywhere hold.

Friedman's arguments, like those of Machlup, helped to intellectually justify the approach taken by neoclassicists to la- bor market issues. Another early contribution to the debate about how economic theory applies to "real" labor markets was made by Simon Rottenberg (1956). Rottenberg directly confronted four neoinstitutionalist assertions concerning job choice: that "personal" reasons are cited by workers as more important than the structure of wages when they are interviewed about their occupational choices; that workers' choices are made under conditions of ignorance; that workers' concern for job security dominates their sensitivity to the wage structure; and that workers do not act rationally in labor markets. Economic theory, Rottenberg pointed out, posits that job choice is multi-dimensional and that predictions based on this theory are made holding other things equal. Theory, he argued, does not hold that wages are the only thing that matters; rather, wages are one of the variables considered when making a choice. Moreover, interview responses are to be distrusted, both because respondents tend to focus on a single dimension when explaining choice and because they are reluctant to admit their behavior is affected by materialistic motivations. Further, to say that information is imperfect and that estimations of various job conditions have to be made when making a decision under conditions of uncertainty does not imply that workers cannot act rationally. In sum, Rottenberg, Machlup, and Friedman combined to provide important clarifications about both the role of theory and how to assess its usefulness in explaining "real" labor-market phenomena.

\section{The "Reach" of Neoclassical Theory}

But how widely, and to what questions, could neoclassical theory usefully be applied? Economics, like many sciences, can be divided roughly into theoretical and applied fields. While theoretical fields in economics are abstract and in the postwar period attracted those inclined to see the beauty of mathematics, the applied fields continued to attract scholars interested in practical problems and issues of public policy. Labor market scholars are usually 
of the latter variety, and for these scholars to become convinced that economic theory could be creatively applied to analyses of important labor-market issues required that such theory be focused both on the generation of empirically testable implications and on socially interesting topics, even if heretofore not seen as within the purview of economics.

In the immediate postwar period, the discipline of economics had been invigorated by such scholars as Ragnar Frisch, Jan Tinbergen, and Paul Samuelson-the first winners of the Nobel Prize in economicswho increased the degree of formalization in both theory and empirical application. On the theoretical side of this mathematical revolution, neoclassical theory was recast with the use of rigorous derivations, which spawned new interest in the field: "While institutionalists and many neoclassicists in the interwar period felt that price theory had been completed ... the years after World War II witnessed a flood of articles, each focusing on a certain element of the theory, couching it in a newly born jargon, and deriving rigorous conclusions out of it" (Yonay 1998:186).

On the empirical front, the field of econometrics - the application of statistical quantification to tests of theoretical propositions-developed and then exploded after the mid-1960s when the computer made it possible to perform highly complex calculations in minutes (and, later, seconds). These changes in economics at large helped attract to the field of labor economics some innovative pioneers who could envision the application, and empirical testing, of neoclassical theory in a variety of "realistic" labor-market contexts.

One such pioneer was H. Gregg Lewis, who has been called the "father of modern labor economics." Lewis was greatly influenced by theorists at the University of Chicago, where he was both a student and professor. While he authored a "classic" book and several important articles, his contribution to the field was "achieved more through teaching and criticism than through publication" (Rees 1976:83-84). It is difficult to think of an early leader among modern labor economists who was neither a colleague of Lewis while formulating a seminal work nor among almost 90 Ph.D. students he supervised over the years. ${ }^{11}$

In 1957 Lewis published a paper in which the secular decline in hours of work was analyzed using neoclassical economic theory; that Lewis's intellectual heritage was squarely in economic theory was indicated by the statement, made early in the paper, that "our approach is orthodox: mainly the theory of the demand for leisure viewed as a consumption good." Lewis's classic book, Unionism and Relative Wages in the United States (1963), analyzed a traditional topic in a new way. Instead of focusing on-the history, governance, and tactics of unions, as had the neoinstitutionalists, Lewis confined his work to a question upon which economic theory could empirically contribute: the effects of unions in raising the wages of their members relative to those of nonunion workers. ${ }^{12}$

While Lewis's work on unions looked at an old topic in a new way, his student (and later a colleague) Gary Becker broadened the scope of issues to which economic theory was addressed. Becker believed that economic analysis was applicable to a wide range of social phenomena, not just the characteristics of producers and consumers traditionally of interest to theorists. In his view, the applications of economic theory were better defined by methodology than by topic: "The combined assumptions of maximizing behavior, market equilibrium, and stable preferences, used relentlessly and unflinchingly, form the heart of the economic approach as I see it" (Becker 1976:5). Becker's writings and his attitude were fundamental to the development of modern labor economics.

\footnotetext{
"Lewis served on the faculty supervising committee of the doctoral dissertations of Gary Becker, Glen Cain, Thomas Finegan, Marvin Kosters, Robert Lucas, Walter Oi, Donald Parsons, Albert Rees, Sherwin Rosen, and Finis Welch, among others.

, Lewis continued to study the issue and published a second book on the union wage effect more than two decades later: see H. G. Lewis (1986).
} 
Becker made several major contributions that were particularly significant to the emergence of neoclassical labor economics. In 1957 he published The Economics of Discrimination, in which he posited that a person with a "taste for discrimination" will act "as if he were willing to pay something, either directly or in the form of a reduced income, to be associated with some persons instead of others" (Becker 1957:14). Based on this concept, Becker provided a framework with which to analyze and measure a social problem that is too important to be poorly analyzed and understood.

Becker also was one of the pioneers, along with Theodore Schultz (1963) and Jacob Mincer (1962b), in the development of the theory of human capital. In Human Capital (1964), he argued that education and on-the-job training should be viewed as forms of investment, and that individuals' and firms' decisions concerning the amount to invest are based on a comparison of costs with the expected future returns to these investments. Further, as a much-cited article by Walter Oi (1962) pointed out, employers' decisions concerning the use of overtime and layoffs in response to product demand fluctuations are critically affected by their prior (and expected future) investments in the hiring and training of workers. Human capital theory was extended to the issue of migration by Larry Sjaastad (1962), opening up a rich literature on both the causes and effects of geographic and job mobility. Taken together, these theoretical developments opened up serious study of employee and employer behaviors that critically affect job stability, the acquisition of skills, and locational choiceand hence the level of individual wages, the distribution of earnings, and the demand for formal and informal schooling (which together create the skills that constitute over half of our stock of national wealth).

Becker's third major contribution has become known as the theory of household production. In his 1965 paper, "A Theory of the Allocation of Time," Becker viewed household activities as the combination of time and goods to produce commodities that yield happiness: meals, leisure activi- ties, clean living spaces, and the like. The cost of time at home is measured by forgone earnings; thus labor supply and household decisions are intertwined. Becker's work on household production, along with Mincer's 1962 paper, "Labor Force Participation of Married Women," represented attempts "to place the theory of labour supply in the context of family decisionmaking, combining non-market household behaviour with market behaviour" (Blaug 1985:165). Mincer (1962a) found that married women's participation rates were negatively related to their family's income (the "income effect") and positively related to their own wage rates, holding income constant (the "substitution effect"). Lewis's (1957) earlier study of trends in work hours, along with Mincer's careful measurement and empirical estimation of income and substitution effects, marked the beginning of "modern research on labor supply" (Pencavel 1986:5). The work on labor supply by Becker and Mincer permitted and encouraged widespread analysis of the rising labor force participation of women and the labor supply effects of social welfare programs.

George Stiglerwas another path breaker. In the early 1960s, Stigler $(1961,1962)$ developed the economic theory of information and its labor sub-field, the theory of job search. ${ }^{15} \mathrm{He}$ argued that information is

More recently, Becker has generalized his theory of household production to include various aspects of family behavior. In A Treatise on the Family (1981), he analyzes "marriage, births, divorce, division of labor in households, prestige, and other nonmaterial behavior with the tools and framework developed for material behavior" (p. ix).

Other major studies of labor force participation published in the 1960s include Cain (1966) andBowen and Finegan (1969). The labor supply effects of income maintenance programs are analyzed in Cain and Watts (1973).

The theory of $\mathrm{j}$ ob search was first suggested by W. H. Hutt (1939:59-60), who maintained that an unemployed worker who is actively searching for a job "is really investing in himself by working on his own account without immediate remuneration. $\mathrm{He}$ is prospecting... . He judges that the search for a better opening is worth the risk of immediately foregone income." 
a valuable resource that is costly to obtain. An unemployed person looking for work, "unless his degree of specialization is pathological," faces "an immense number of potential employers" and needs to determine "how to acquire information on the wage rates, stability of employment,... [and working conditions] which would be obtained from every one of these potential employers" (Stigler 1962:94). Information is obtained by engaging in the costly activity of job search, and Stigler argued that a maximizing worker will continue to search "until the expected return equals the marginal cost of search" (1962:96). Because search is both necessary and often cheaper when one is unemployed, and because the presence of unemployment insurance effectively subsidizes continued search, Stigler's contributions opened up new insights useful to the analysis-and to some extent, the remediation-of unemployment.

While Stigler's work on information and search costs had relevance to unemployment, it also could be used to address a phenomenon that had contributed to the neoinstitutionalists' deep suspicion of standard theory: the existence of wage differentials in markets where the "law of one price" was predicted to hold. Indeed, the issues of unemployment and wage differentials nicely illustrate the very different mindsets of the neoclassical labor economists and their neoinstitutionalist predecessorsa topic to which we will shortly turn.

\section{Intellectually Coping with Inconvenient Facts}

One fundamental tenet of basic price theory is that the forces of demand and supply drive all markets into market-clearing equilibrium. If a price is set above equilibrium, for example, supply will exceed demand, and the responses of profitmaximizing firms and utility-maximizing worker/consumers will eventually drive the price down toward equilibrium. The lower price will increase the quantity demanded and reduce the quantity supplied, with the result that the excess supply is reduced or eliminated. If the labor market can be analyzed like any other market, as Hicks had claimed, the persistence of unemployment seemed to constitute a major contradiction of an important theoretical implication; indeed, in the words of institutionalist Dale Yoder (1933:119), "Unemployment must be regarded as deviation away from what might be expected to be the normal condition."

One characteristic of the neoclassical labor economists-and one that sharply distinguished them from the neoinstitutionalists-was their dogged determination to find maximizing behavior and equilibrium outcomes throughout the labor market. Stigler's insights on search made it possible for at least some share of overall unemployment to be seen as both voluntary and a characteristic of equilibrium. If search is cheaper when a worker is not encumbered by ajob, and if it is not always optimal for an unemployed worker to take the first job offered, then job seekers could be seen as rationally choosing unemployment under certain conditions. Armen Alchian (1970:29-30) described such unemployment as "self-employment in information collection." The economic theory of job search was further developed by Dale Mortensen (1970a, 1970b) and J. J. McCall (1970), whose work demonstrated that "search unemployment" was an equilibrium outcome of voluntary behavior on both sides of the labor market. These papers set the stage for an explosion of theoretical and empirical research in the 1970s and 1980s on the economics of search in the labor market. ${ }^{16}$

It had long been observed by both institutional and neoclassical economists that cyclical declines in the demand for labor

This enormous body of research is surveyed in Devine and Kiefer (1991). Another view of "voluntary" unemployment arising from (utility) maximizing behavior was suggested by Lucas and Rapping (1969); in this model, some workers withdraw their labor supply-for the purpose of consuming leisurewhen their individual wage falls below its normal (or "permanent") level. 
did not lead to declines in wages by enough to clear the labor market, as predicted by economic theory. Rather, firms tended to temporarily lay off workers during downturns. The absence of market-clearing wages and the use of layoffs seemed to be further proof that neoclassical labor economics was not realistic. In the mid-1970s, Costas Azariadis (1975), Martin Baily (1974), and Donald Gordon (1974) independently developed the theory of implicit contracts, which provided an economic rationale for temporary layoffs. According to implicit contract theory, because workers dislike risk while firms are risk-neutral,

a mutual gain is available to employers and employees ... [compared] to a world of purely auction labor markets. Employees will, to some degree, prefer a lower expected wage with a smaller variance to a larger more uncertain income. In the interest of getting cheaper labor, employers can enter into implicit longterm quasi-contracts with their employees by guaranteeing them some reasonable security. (Gordon 1974:78)

The original implicit contracts models assumed that all workers in a firm were identical, and that any layoffs that occurred were therefore random. Because the share of workers laid off even during serious downturns was relatively small, and the average duration of temporary layoffs was short, contracts containing "sticky" wages and layoffs offered more income security than contracts in which firms responded to downturns by cutting all workers' wages. The existence of unemployment insurance made contracts containing temporary layoffs even more attractive to both firms and workers (Feldstein 1976).

A similar line of reasoning can be used to explain why implicit contracts exist in the real world where workers are not identical. Firms with long employer-employee job attachments may be encouraged by older workers' risk aversion to engage in seniority-based layoffs rather than wage cuts for all workers. Younger workers may be willing to accept such contracts if they know that layoffs are temporary and that they will eventually attain enough seniority with the firm to become "older" workers. Feldstein
(1976) found that "most workers who are laid off are subsequently rehired by their original employers," and concluded that "because workers remain with the same employer through several spells of unemployment, the frequency and duration of temporary layoffs must be regarded as part of the total package of compensation and conditions.... Although any particular layoff may be involuntary, the general pattern of temporary layoffs may be an explicit part of labor contracts" (1976:937-38). In sum, it is the view of neoclassical labor economists that layoff unemployment is not inconsistent with economic theory. ${ }^{17}$

How neoclassical labor economists dealt with the issue of wage differentials is perhaps even more instructive. Elementary economic theory strongly implies that workers who have equivalent skills and jobs with the same nonpecuniary characteristics will receive identical wages. ${ }^{18}$ This one price should prevail, because if it did not, either workers in lower-paying jobs would migrate to the higher-paying ones, or the higherpaying employers would be driven by competition in the product market to reduce their wages. Therefore, an implication of simple theory is that, absent temporary disequilibria, observed wage differentials should be related empirically only to the supply (that is, human capital) characteristics of workers or the nonpecuniary aspects of their jobs - and not to the industry, size, or "ability to pay" of their employers. The problem for labor economists is that this implication is contradicted by the data, which suggest the existence of persistent wage differentials among firms hiring from the same labor market. Indeed, the prob-

\footnotetext{
"Implicit contract theory is surveyed in Rosen (1985). Burdett and Mortensen (1980) provide a synthesis of search and implicit contract theory.

The theory of wage differentials that compensated for nonpecuniary differences injobs, originally outlined by Adam Smith, was fully developed by Sherwin Rosen (1974) in an influential paper thatwas seminal to a burgeoning empirical literature on compensating wage differentials.
} 
lem of wage differentials was a cornerstone of neoinstitutionalists'distrust of economic theory: "It is the apparent failure of local rates to equalize which has long been seized upon by critics of competitive theory as their prime exhibit" (Reder 1962:312). ${ }^{19}$

The neoinstitutionalists had explained these theoretically embarrassing wage differentials in a number of ways that they believed undermined the neoclassical model. Reynolds, in his 1970 text (pp. 101 17), pointed to a numberoipotential explanations: wages that were downwardly inflexible, internal labor markets, discrimination, "anti-pirating" agreements among employers, unionism, poor information, restricted entry to occupational training programs, the failure of firms to maximize profits, and sheer tradition. While these scholars were clearly seeking generalizations, none cast their analyses in terms of neoclassical theory (that is, using a sparse model of maximizing behavior in the face of competition and constraints).

Melvin Reder, at Stanford, was among the first of the "modern" labor economists to directly address the issue of wage differentials apparently associated with employer (including industry) characteristics. In a 1962 paper on the topic of demand-side wage differentials he revealed an attitude very characteristic of the neoclassical labor economists:

Most discussions of interindustry wage differentials proceed without much explicit consideration of economic theory. The literature abounds in ad hoc hypotheses, some of which are consistent with economic theory but many of which are not. However, these various hypotheses are usually treated as being equally plausible, a priori; consistency with the implications of price theory has counted for very little in appraising the merits of a theory. Our attitude is somewhat different; we believe that if a theory is inconsistent with the implications of

\footnotetext{
${ }^{19}$ Reder's views of the early 1960 s are echoed today by Kaufman (1994:146), who says that "the single most important empirical issue in labor economics is the degree to which labor markets are competitive."
}

price theory it is cause for concern, and that an explanation is in order. (Reder 1962:276)

To Reder and others of the same stripe, neoclassical theory was innocent until proven guilty, and like good defense lawyers, they readily marshaled plausible alibis and mitigating circumstances when the facts looked damning. On the topic of why interindustry wage differentials did not show signs of disappearing over time, as theory suggested should happen, Reder invoked two defenses that were to become fairly standard: the data observed might inadvertently be from periods that exhibited short-run disequilibria, and the studies might not have controlled for all the variables that influenced the observed outcome (in this case, possible changes in the geographical distribution of firms and the occupational skill mixes within industries).

While Reder did concede that the persistence of interindustry wage differentials could imply that the competitive hypothesis was wrong, the internal logic of elementary neoclassical theory was clearly compelling enough to prevent his theoretical hide from being easily dented by mere facts. He reasoned that, "to be sure, there is a tendency for out-of-line wages to be corrected as soon as the 'opportunity presents itself,' but it is also true that large firms are more dilatory about correcting overpayment" (Reder 1962:285). He immediately allowed that this dilatory behavior was "not explained by the competitive hypothesis," but undaunted, he concluded his paper by arguing that the competitive hypothesis had not been disproved. He reasoned that "it can hardly be said to be firmly established as an explanation of wage phenomena even for long periods; but it has at least survived (reasonably well) the tests to which it has so far been put" (Reder 1962:298). Thus, Reder's attitude, like that of other neoclassicists, was essentially that models assuming maximizing behavior can explain labor-market phenomena if only researchers are well-enough endowed with data and methodologies to apply the appropriate empirical tests.

Reder's unswerving allegiance to neo- 
classical theory was testimony to the intellectual appeal of a simple, internally consistent model of behavior. To a neoclassical economist, the logic of price theory was so utterly convincing-especially in the absence of a competing theory-that logic itself was called upon to settle what appeared to be empirical disputes. Paul Samuelson, for example, had this to say in the 1951 edition of his textbook:

The fact that a firm of any size must have a wage policy is additional evidence of labor market imperfections ... But just because competition is not 100 per cent perfect does not mean that it must be zero. The world is gray, not black or white ... If you try to set your wage too low, you will soon learn this. At first nothing much need happen, but eventually you will find your workers quitting a little more rapidly than otherwise would be the case. (Samuelson 1951b:598)

In this passage, Samuelson is dealing with the empirically based charge that small changes in wages do not always cause workers (or customers) to immediately move from poorer opportunities to better ones, as posited by elementary theory. Instead of arguing that elementary theory is inadequately realistic, however, or presenting empirical data to show that market behavior actually is consistent with theoretical predictions, Samuelson reasons from sheer logic: even if labor-market mobility is restricted for some reason, it must surely be the case that in the long run employers who depart from paying market wages will be punished. He might have added, "What other outcome could there be?" Without another theory that was equally appealing in terms of its logic, those with an analytic inclination could imagine no outcomes other than those implied by price theory.

\section{Inside the Firm and Work Groups: Neoclassical Approaches to Neoinstitutionalist Interests}

In 1971 Peter Doeringer and Michael Piore published an important book, Internal Labor Markets and Manpower Analysis, that in many ways picked up where the early postwar neoinstitutionalists had left off. The book expanded on earlier studies by Reynolds, Kerr, and Dunlop. ${ }^{20}$ Reynolds (1951) had concluded from his study of labor markets in a medium-sized New England city that "each company employment office is really a distinct market for labor" (p. 42). He found that wage dispersion across firms was "very substantial," and that "nonwage terms of employment... tend to accentuate wage differences rather than to offset them" (pp. 221-22). Kerr (1954), in his famous paper on the "balkanization" of labor markets, developed the concept of "institutional" labor markets that were governed by formal and informal rules rather than by economic variables. These institutional labor markets "create truly noncompeting groups." The rules set sharp "boundaries between the 'internal' and 'external' [labor] markets and define more precisely the points of entrance.... Workers inside the market... are not in direct competition with persons outside." The term "internal labor market" was coined by Dunlop (1966), who maintained that both unionized and nonunionized employers "tend to develop an elaborate set of practices or rules relating to promotions, transfers, layoffs, and retirements for various groups of job classifications; they confine entry from outside the organization ... to a limited number of classifications" $(1966: 32) .^{21}$

Doeringer and Piore (1971:2-3) defined an internal labor market as "an administrative unit, such as a manufacturing plant, within which the pricing and allocation of labor is governed by a set of administrative rules and procedures." This internal labor

Both Doeringer and Piore were students of John Dunlop at Harvard.

In an earlier paper, Dunlop (1957:135) presented a table of the average hourly wages for unionized truck drivers in Boston in July 1953. The table showed that the wages varied sharply across industries. However, wages for truck drivers within a "wage contour" (basically an industry) tended to be equal. He concluded that these wage contours had developed over time, and that they demonstrated that a "perfect labor market" did not exist (pp. 135-37). 
market was distinguished from the external labor market, "where pricing, allocating, and training decisions are controlled directly by economic variables." Movement between the two labor markets

occurs at certain job classifications which constitute ports of entry and exit to and from the internal labor market. The remainder of the jobs within the internal market are filled by the promotion or transfer of workers who have already gained entry. Consequently, these jobs are shielded from the direct influences of competitive forces in the external market. (Doeringer and Piore 1971:3)

Doeringer and Piore (1971, Chapter 8) also examined the implications of dual labor market theory, originally developed by Piore (1969). This theory postulates that the labor market is divided into primary and secondary markets. Jobs in the primary sector are high-paying, with good working conditions, employment stability, and chances for promotion. In contrast, jobs in the secondary market are low-paying, with high turnover, poor working conditions, and little chance for promotion. Disadvantaged workers "are confined to the secondary market by residence, inadequate skills, poor work histories, and discrimination" (p. 166). Primary sector jobs are associated with internal labor markets; some secondary jobs are "completely unstructured," while others are attached to internal labor markets, although they include few, if any, of the privileges typically associated with such labor markets.

Further analysis of internal labor markets and dual labor markets has been done by Bennett Harrison (1972), David Gordon (1972), Lester Thurow (1975), Edwards, Reich, and Gordon (1975), and Paul Osterman (1975, 1984), among others. These studies examine individual firms' hiring and pay practices, the reasons for the existence of internal labor markets, and the consequences of internal labor markets for the distribution of earnings and differential economic opportunity. Given the influence of Dunlop and Kerr on these scholars, one is tempted to refer to them as "neo-neoinstitutionalists."
The literature on internal labor markets, and the seeming inconsistencies of important labor-market outcomes with the predictions of simple neoclassical theory, challenged neoclassical labor economists to expand their analyses of wage determination beyond their traditional focus on market tendencies - and to regard as worthy of analysis the wage setting practices by individual employers. Moreover, at least partly in response to the neo-neoinstitutionalist literature, neoclassical economists have begun to widen their "homo economicus" view of economic agents as narrowly selfserving and autonomous, to include considerations of social interdependency and context.

For example, the theory of efficiency wages offers explanations based on maximizing behavior both for the existence of wage differentials for workers with similar characteristics and for the payment of wages in excess of market-clearing levels. According to this theory, higher wages affect the net productivity of workers by reducing their propensity to quit and by increasing their levels of effort. Profit-maximizing employers are willing to pay above marketclearing wages, because such a strategy increases labor productivity more than it increases costs (Akerlof and Yellen 1986). Efficiency wage theory offers an explanation for wage dispersion and for dual labor markets: the "wage-productivity nexus" is more important in some sectors of the economy than in others. In the primary sector, where the wage-productivity nexus is assumed to hold, workers are paid above market-clearing wages; in the secondary sector, where above-market wages are not profitable, labor markets clear (Yellen 1984:201). Bulow and Summers (1986) constructed a model of dual labor markets based on the causal relationship between wages and productivity, and used it to explain interindustry and intraindustry wage differentials, discrimination, and involuntary unemployment.

A recent version of efficiency wage theory, the "fair wage-effort hypothesis" (Akerlof and Yellen 1990), contends that workers will withhold effort if they are paid a wage 
below what they consider to be fair. It is possible that the fair wage exceeds the market-clearing wage (1990:255-56). The "fair wage-effort hypothesis" is one possible explanation for the interindustry wage differentials (for workers with similar skills in similar jobs) found by the neoinstitutionalists-for example Slichter (1950) and by Dickens and Katz (1987) andKrueger and Summers (1987, 1988). According to Akerlof and Yellen (1990:265), "if firms must pay a high wage to some groups of workers-perhaps because they are in short supply or perhaps to obtain high qualitydemands for pay equity will raise the general wage scale for other labor in the firm, who would otherwise see their pay as unfair." 22

The importance of fairness in labor markets was also discussed by Nobel laureate Robert Solow in his book, The Labor Market as a Social Institution (1990). Solow contended that "the fundamental reason for believing that fairness is a factor in labor markets is what we know about our own society and culture.... Once you admit to yourself that wage rates and employment are profoundly entwined with social status and self-esteem you have already left the textbook treatment of the labor market behind" (pp. 9-10). Robert Frank argued in his book, Choosing the Right Pond: Human Behavior and the Quest for Status (1985), that individuals place a value on status in their local reference group, and that this can explain why within-firm differences in individuals' wages are often smaller than differences in their marginal products. The publications discussed above all encompass social interdependencies in a theoretical model, thus allowing concerns for "fairness" and status to be associated with maximizing behavior in a context of markets and constraints. Finally, it could be said,

Katz and Summers (1989) offer another explanation for interindustry wage differentials: workers in certain industries are able to extract rents-in the form of wages in excess of their best alternativesfrom their employers. issues that were so important to the neoinstitutionalists are being addressed by price theorists. ${ }^{23}$

In recent years, neoclassical economists have begun to model several other labormarket characteristics or outcomes that seem at first blush to be inconsistent with the predictions of neoclassical theory. Edward Lazear $(1979,1981)$, for example, has dealt with the issue of why older workers might be paid more than their marginal products. Lazear and Sherwin Rosen (1981) and Rosen (1986) raised the issue of why small differences in productivity among top executives can lead to huge differences in pay, while James Brown and Orley Ashenfelter (1986) took a new look at an older issue raised by Dunlop: why firms (and their unions) have latitude within which they can design their internal compensation structures. Indeed, a new textbook by Lazear, entitled Personnel Economics for Managers (1998), now applies the principles of rigorous economic reasoning to a variety of human-resource management issues (hiring, training, paying, motivating, and promoting workers) of long-standing interest to the neoinstitutionalists (see also Lazear 1995). Unlike the neoinstitutionalists, however, neoclassical labor economists have built their studies of firm behavior upon models of maximization in the face of constraints (Baker, Gibbons, Murphy 1994; Holmstrom and Milgrom 1994).

\section{Neoclassical Labor Economics and Public Policy}

By the early 1970s, neoclassical economists had become prominent enough that they substantially contributed, both philosophically and empirically, to the national debate that ended military conscription in the United States (President's Commission

\footnotetext{
"Neoclassical economists' interest in fairness is not new, although one could argue that it has been suppressed for some time. In 1883 Alfred Marshall wrote a paper entitled "A Fair Rate of Wages." The paper is reprinted in Marshall (1925:212-26).
} 
onan All-Volunteer Armed Force 1970). It was increasingly recognized that economic theory and the measurable implications that could be derived from it were useful for understanding the effects of labor market institutions and policies. Neoclassical labor economics thoroughly adopted econometric techniques as a means of extending "dry bones" theory into the real world of institutions and government programs.

One of the areas to which neoclassical labor economists turned their attention was labor supply behavior, spawned in part by the negative income tax experiments of the late 1960s and the 1970s. Significant advances in the way in which labor supply models were econometrically specified and estimated were made early on by Orley Ashenfelter and James Heckman (1974) and Heckman (1974), with later additions by Heckman and Thomas MaCurdy (1980), MaCurdy (1981), Ashenfelter (1983), and Joseph Altonji (1986), among others. Heckman (1979, 1980) developed a now widely used statistical technique to correct for the selectivity bias that occurs when individuals in one group (for example, workers) differ from those in the other (those choosing not to work) in ways that are not easily measured.

Research in the area of human capital mushroomed, with an early focus on the rates of return to personal and social educational investments (Hanoch 1967; Griliches 1970). These early interests, central to issues of educational policy, led directly to new empirical techniques to deal with possible problems of "ability bias" and self-selection associated with estimating the returns to schooling, and to more recent studies of the effect of school quality on student achievement and future earnings. ${ }^{24}$ Job training programs, which were part of President Johnson's Great Society in the

On ability bias and selection bias, see, for example, Griliches (1977), Willis and Rosen (1979), Ashenfelter and Krueger (1994), and Card (1995). On the effects of school quality, see Hanushek (1986) and Card and Krueger (1992). later 1960s, also became an object of study by analytical labor economists; Ashenfelter's (1978) analysis of the effects of government training programs on the post-training earnings gains of trainees is an early example of a study examining the costs and benefits of public sector training.

Other policy-related areas of research that attracted neoclassical scholars touched on issues of immigration, gender, and race. Barry Chiswick (1978), and later George Borjas (1985, 1987, 1990) and David Card (1990a), contributed analyses of the economic effects of immigration. ${ }^{25}$ The sharp increase in female labor force participation since World War II was mirrored by an increase in research on women in the workplace. Early studies measuring the size of and offering explanations for-male-female earnings differences were undertaken by Ronald Oaxaca (1973), Jacob Mincer and Solomon Polachek (1974), and Francine Blau (1977), while Blau and Lawrence Kahn (1996, 1997), Claudia Goldin (1990), and Blau and Ehrenberg (1997) offer more recent perspectives of the problems and progress experienced by the female labor force. Following the lead of Gary Becker, neoclassical labor economists also sought to measure and explain the economic disadvantages faced by the African-American labor force. Early work by Ashenfelter $(1970,1972)$ and the authors in Ashenfelter and Rees (1973) was followed by a robust literature summarized in Donohue and Heckman (1991).

The study of unions, long of interest to government policy-makers and labor economists alike, was broadened beyond the estimation of unions' wage effects. The model of labor-management bargaining and strike activity originally postulated by Hicks (1932) was expanded to include union leadership and rank-and-file as separate parties and statistically tested by Ashenfelter and George Johnson (1969) and Henry Farber (1978). Empirical tests of the asymmetric-

\footnotetext{
${ }^{25}$ See also the papers in Abowd and Freeman (1991) and Borjas and Freeman (1992).
} 
information model of strike activity were undertaken by Joseph Tracy (1987) and David Card (1990b).

In 1984, two neoclassical labor economists, Richard Freeman and James Medoff, published a book entitled What Do Unions Do?, in which they argued that neoclassical economists had produced "very little quantitative evidence concerning the impact of U.S. unionism on outcomes other than wages," and that they generally ignored the neoinstitutionalists' view that unions often raise productivity and induce better management. Freeman and Medoff used newly available computerized data files, which contained vast amounts of information on thousands of individuals, establishments, and companies, to statistically analyze "many of the nonwage effects of trade unions" (pp. 4-5). Their results indicated that many of the neoinstitutionalists' observations concerning unions were correct. In particular, they found that unions raised productivity in many sectors of the economy, largely as a result of lower rates of turnover under unionism and of "improved managerial performance in response to the union challenge" (pp. 21-22). While the conclusion that the positive aspects of unionism usually outweighed the negative (monopoly) aspects remains open to question (see Hirsch 1991), the issue is one that has important policy implications for a society that still debates whether the government should take a more (or less) active role in encouraging the growth of union power.

In addition to interests in the longstanding policy issues regarding unions, discrimination, education, and immigration, neoclassical labor economists began attempts (following Rosen 1974) to identify and measure market failures as they related to the relatively new "social" regulation of workplace safety (see Smith 1979; and later, Viscusi 1993). In addition, the "adverse incentives and distributional anomalies" of the U.S. system of unemployment compensation noted by Feldstein (1974) were examined by Ehrenberg and Oaxaca (1976), Hamermesh (1977), Brechling (1977), Topel (1983), and Burdett and Wright (1989).
The energy and frequency with which theory was being applied by labor economists to issues of social and economic policy raised the question of whether the modern approach could go very far beyond the walls of academe and be widely useful for policy purposes. John Dunlop thought not: "Tests of the elegance, coherence, and generality of economic and industrial relations models and theories are intellectually exciting and challenging, but their relevance and application to policy making is scarcely within the reach of most researchers" (Dunlop 1977).

Neoclassical labor economists (Ehrenberg et al. 1977) strongly demurred, arguing that the Carter administration's policy decision to tax unemployment insurance benefits was but one contemporary example of the influence on public policy of neoclassical analysis (which had demonstrated that higher benefits encourage longer spells of joblessness). By the 1980s neoclassical labor economists had become so intimately involved with policy analyses-for the Council of Economic Advisors; the Department of Labor; the Department of Health, Education and Welfare; the Equal Employment Opportunity Commission; international development agencies; the Congressional and Executive Budget Offices; and even the CIA - that they were forced to give more attention to issues raised by the institutionalists.

The greater interest of neoclassical labor economists in public policy issues, and their growing influence, forced three major changes in the field. First, because one cannot understand public policy issues without a thorough grounding in institutional detail, neoclassical labor economists necessarily became more institutional in their interests. Seemingly small administrative details about how unemployment or workers' compensation insurance premiums are set, for example, have huge implications for the layoff or safety behavior of employers; labor economists wanting the ear of policy-makers had to know these details. Moreover, institutions have histories that both reflect and affect behavior; the ahistorical approach of pure theory might 
yield behavioral tendencies, but usually a larger context is required if sensible policies are to be promulgated. Daniel Hamermesh's 1977 book on unemployment compensation, which was aimed at an audience much wider than professional economists, was but an early example of the kind of attention that is now routinely given to institutional details by neoclassical labor economists studying welfare programs, immigration, workers' compensation, international comparisons of job training, and many other labor market issues.

Second, along with greater prominence in public policy came greater responsibility for the accuracy and credibility of empirical results. Few in society care in the abstract about whether capital and labor are used under conditions of constant elasticity of substitution in the mining of coal, but if the implicit tax of the Black Lung Benefits Program is being debated, the conditions under which coal is produced matters very much because real jobs are on the line. The quality of one's data, and the statistical specifications and methods used, began to really matter when the answers started to affect lives instead of "dry bones" abstractions. Interestingly, the lively disputation over the findings of David Card and Alan Krueger (1995) relative to the minimum wage'have mostly focused on the quality of data and the replicability of statistical estimates (Neumark and Wascher 1997; Card and Krueger 1997).

Third, greater policy prominence required labor economists to write for new audiences-people who are intelligent but not necessarily schooled in the use of economicjargon or patient with complex equations. In the 1990s, for example, various issues of the Economic Report of the President addressed labor-market topics requiring non-technical treatments of such concepts as labor supply theory (1992:148), compensating wage differentials (1993), the natural rate of unemployment (1994), the returns to human capital investments (1996), and distinguishing labor demand from labor supply shifts as explanations of growing wage inequality (1997). When their research began to matter to others besides their colleagues, labor economists had to use ordinary English instead of jargon. Congressman Lee Hamilton recently wrote: "For me, the most important quality for economists to have when they are testifying or advising policy-makers is the ability to express their ideas on important policy issues clearly and simply, without jargon" (Hamilton 1992:61).

Recentyears, therefore, have seen movement away from some of the more academically insular features of "pure" neoclassical analyses of the labor market toward including some "realistic" characteristics of the institutionalist approach. More researchers are collecting their own data, and more are now relying on case studies (often, "natural experiments") involving some exogenous economic or policy change to create the comparisons needed for hypothesis testing. ${ }^{26}$ Even controlled experiments have been run, both inside and outside the laboratory.

Thus, the stated mission of the neoinstitutionalists-causing simple price theory to adapt to the unique realities of the labor market-seems to be on its way to fulfillment. Neoclassical labor economists are now-at long last, some would sayaddressing some of the issues that had so consumed the interest of neoinstitutionalists, and they have turned out to be similar to their neoinstitutionalist predecessors in the fundamental desire to understand how employers and employees really behave. While "dry bones" neoclassical theory provides the skeletal framework for modern analyses, empirical flesh and blood still provides labor economists with the motivation. Early empirical work using large data sets and advanced computing techniques provided general support for some theoretical implications but offered disappointing results regarding others; further scientific advances therefore required taking more sophisticated account of social and

\footnotetext{
${ }^{26}$ See, for example, Card (1990a) on the labor market effects of the Mariel boatlift, and Meyer, Viscusi, and Durbin (1995) on supply responses to changes in workers' compensation benefits.
} 
institutional idiosyncrasies. If the new areas of inquiry within neoclassical labor economics are in fact driven by the imperatives of science, then the neoinstitutionalist interests may permanently fuse with the neoclassical approach.

\section{REFERENCES}

Abowd.John M., and Richard B. Freeman, eds. 1991. Immigration, Trade, and the Labor Market. Chicago: University of Chicago Press.

Adams, Thomas, and Helen Sumner. 1905. Labor Problems. New York: Macmillan.

Akerlof, George A., andJanetL. Yellen. 1986. "Introduction." In George Akerlof and Janet Yellen, eds., Efficiency Wage Models of the Labor Market. Cambridge, U.K.: Cambridge University Press, pp. 1-21. Akerlof, George A., andJanetL. Yellen. 1990. "The Fair Wage-Effort Hypothesis and Unemployment." Quarterly fournal of Economics, Vol. 105, No. 2, pp. 255-83.

Alchian, Armen A. 1970. "Information Costs, Pricing, and Resource Unemployment." In Edmund S. Phelps et al., eds., Microeconomic Foundations of Employment and Inflation Theory. New York: W. W. Norton, pp. 27-52.

Altonji,Joseph G. 1986. "Intertemporal Substitution in Labor Supply: Evidence from Micro Data." Journal of Political Economy, Vol. 94, No. 3, pt. 2, pp. S176-S215.

Ashenfelter, Orley. 1970. "Changes in Labor Market Discrimination over Time." Journal of Human Resources, Vol. 5, No. 4, pp. 403-30.

1972. "Racial Discrimination and Trade Unionism." Journal of Political Economy, Vol. 80, No. 3, pt. 1, pp. 435-64.

1978. "Estimating the Effect of Training Programs on Earnings." Review of Economics and Statistics, Vol. 60, No. 1, pp. 47-57.

- 1983. "Determining Participation in IncomeTested Social Programs." Journal of the American Statistical Association, Vol. 78, pp. 517-25.

Ashenfelter, Orley, and James Heckman. 1974. "The Estimation of Income and Substitution Effects in a Model of Family Labor Supply." Econometrica, Vol. 42, No. 1,pp. 73-85.

Ashenfelter, Orley, and George Johnson. 1969. "Bargaining Theory, Trade Unions, and Industrial Strike Activity." American Economic Review, Vol. 59, No. 1, pp. 35-49.

Ashenfelter, Orley, and Alan B. Krueger. 1994. "Estimates of the Economic Returns to Schooling from a New Sample of Twins." American Economic Review, Vol. 84, No. 5, pp. 1157-73.

Ashenfelter, Orley, and Albert Rees, eds. 1973. Discrimination in Labor Markets. Princeton: Princeton University Press.

Azariadis, Costas. 1975. "Implicit Contracts and Underemployment Equilibria." Journal of Political Economy, Vol. 83, No. 6, pp. 1183-1202.

Baily, Martin N. 1974. "Wages and Employment under Uncertain Demand." Review of Economic Studies, Vol. 41, No. 1, pp. 37-50.

Baker, George, Robert Gibbons, and KevinJ. Murphy. 1994. "Subjective Performance Measures in Optimal Incentive Contracts." Quarterly Journal of Economics, Vol. 109, No. 4, pp. 1125-56.

Becker, Gary. 1957. The Economics of Discrimination. Chicago: University of Chicago Press.

1964. Human Capital. New York: Columbia University Press.

1965. "A Theory of the Allocation of Time." Economic fournal, Vol. 75, No. 3, pp. 493-517.

- 1976. The Economic Approach to Human Behavior. Chicago: University of Chicago Press.

1981. A Treatise on the Family. Cambridge, Mass.: Harvard University Press.

Blau, Francine D. 1977. Equal Pay in the Office. Lexington, Mass.: Lexington Books.

Blau, Francine D., and Ronald G. Ehrenberg, eds. 1997. Gender and Family Issues in the Workplace. New

York: Russell Sage Foundation.

Blau, Francine D., and Lawrence M. Kahn. 1996. "Wage Structure and Gender Earnings Differentials: An International Comparison." Economica, Vol. 63, Suppl., pp. S29-S62.

- 1997. "Swimming Upstream: Trends in the Gender Wage Differential in the 1980s." Journal of Labor Economics, Vol. 15, No. 1, pp. 1-42.

Blaug, .Mark. 1985. Great Economists since Keynes. Brighton: Wheatsheaf.

Blum, Solomon. 1925. Labor Economics. New York: Henry Holt.

Borjas, George J. 1985. "Assimilation, Changes in Cohort Quality, and the Earnings of Immigrants." Journal of Labor Economics, Vol. 3, No. 4, pp. 463-89.

- 1987. "Self-Selection and the Earnings of Immigrants." American Economic Review, Vol. 77, No.

4, pp. 531-53.

1990. Friends or Strangers: the Impact of Immigrants on the U.S. Economy. New York: Basic Books. Borjas, GeorgeJ., and Richard B. Freeman, eds. 1992. Economic Effects of Immigration in Source and Receiving Countries. Chicago: University of Chicago Press.

Bowen, William G., and T. Aldrich Finegan. 1969. The Economics of Labor Force Participation. Princeton: Princeton University Press.

Brechling, Frank. 1977. "The Incentive Effects of the U.S. Unemployment Insurance Tax." Research in Labor Economics, Vol. 1, pp. 41-102.

Brissenden, Paul. 1926. "Labor Economics." American Economic Review, Vol. 16, No. 3, pp. 443-49.

Brown, James, and Orley Ashenfelter. 1986. "Testing the Efficiency of Employment Contracts." fournal of 
Political Economy, Vol. 94, No. 3, pt. 2, pp. S40-S87. Bulow, Jeremy I., and Lawrence H. Summers. 1986. "A Theory of Dual Labor Markets with Application to Industrial Policy, Discrimination, and Keynesian Unemployment." Journal of Labor Economics, Vol. 4, No. 3, pt. 1,pp. 376-414.

Burdett, Kenneth, and Dale Mortensen. 1980. "Search, Layoffs, and Labor Market Equilibrium." Journal of Political Economy, Vol. 88, No. 4, pp. 65272.

Burdett, Kenneth, and Randall Wright. 1989. "Unemployment Insurance and Short-Time Compensation: The Effects on Layoffs, Hours per Worker, and Wages." Journal of Political Economy, Vol. 97, No. 6, pp. 1479-96.

Cain, Glen G. 1966. Married Women in the Labor Force. Chicago: University of Chicago Press.

1976. "The Challenge of Segmented Labor Market Theories to Orthodox Theory: A Survey." Journal of Economic Literature, Vol. 14, No. 4, pp. 1215-58.

Cain, Glen G., and Harold W. Watts, eds. 1973. Income Maintenance and Labor Supply: Econometric Studies. New York: Academic Press.

Card, David. 1990a. "The Impact of the Mariel Boatlift on the Miami Labor Market." Industrial and Labor Relations Review, Vol. 43, No. 2, pp. 245-57.

1990b. "Strikes and Wages: A Test of an Asymmetric Information Model." Quarterly Journal of Economics, Vol. 105, No. 3, pp. 625-59.

1995. "Earnings, Schooling, and Ability Revisited." Research in Labor Economics, \o\ 14,pp.23-48.

Card, David, and Alan B. Krueger. 1992. "Does School Quality Matter? Returns to Education and the Characteristics of Public Schools in the United States." Journal of Political Economy, Vol. 100, No. 1, pp. 1-40.

1995. Myth and Measurement: The New Economics of the Minimum Wage. Princeton: Princeton University Press.

1997. "A Reanalysis of the Effect of the New Jersey Minimum Wage Increase on the Fast-Food Industry with Representative Payroll Data." Working Paper No. 393, Industrial Relations Section, Princeton University.

Chiswick, Barry R. 1978. "The Effect of Americanization on the Earnings of Foreign-Born Men." Journal of Political Economy, Vol. 86, No. 5, pp. 897-921.

Commons, John R. 1905. Trade Unionism and Labor Problems. Boston: Ginn.

Daugherty, Carroll. 1933. Labor Problems in American Industry. Boston: Houghton Mifflin.

1945. "The Field of Labor Economics." American Economic Review, Vol. 35, No. 4, p. 652-57.

Devine, Theresa, and Nicholas Kiefer. 1991. Empirical Labor Economics: The Search Approach. Oxford: Oxford University Press.

Dickens, William T., and Lawrence F. Katz. 1987. "Inter-Industry Wage Differences and Industry Characteristics." In Kevin Lang andjonathan S. Leonard, eds., Unemployment and the Structure of Labor Markets. Oxford: Basil Blackwell, pp. 48-89.

Doeringer, Peter B., and Michael J. Piore. 1971.
Internal Labor Markets and Manpower Analysis. Lexington, Mass.: D.C. Heath.

Donohue.John H., Ill, and James Heckman. 1991. "Continuous Versus Episodic Change: The Impact of Civil Rights Policy on the Economic Status of Blacks." Journal of Economic Literature, Vol. 24, No. 4, pp. 1603-43.

Douglas, Paul. 1934. The Theory of Wages. New York: Macmillan.

1971. In the Fullness of Time. New York: Harcourt Brace Jovanovich.

Dunlop, John. 1957. "The Task of Contemporary Wage Theory." In George W. Taylor and Frank C. Pierson, eds., New Concepts in Wage Determination. New York: McGraw-Hill, pp. 117-39.

1966. "Job Vacancy Measures and Economic Analysis." In NBER, The Measure and Interpretation of Job Vacancies. New York: Columbia University Press, pp. 27-47.

1977. "Policy Decisions and Research in Economics and Labor Relations." Industrial and Labor Relations Review, Vol. 30, No. 3, pp. 275-82.

Edwards, Richard, Michael Reich, and David Gordon, eds. 1975. Labor Market Segmentation. Lexington, Mass.: Lexington Books.

Ehrenberg, Ronald, Daniel Hamermesh, and George Johnson. 1977. "Policy Decisions and Research in Economics and Industrial Relations: An Exchange of Views." Industrial and Labor Relations Review, Vol. 31, No. 1,pp. 10-13.

Ehrenberg, Ronald, and Ronald Oaxaca. 1976. "Unemployment Insurance, Duration of Unemployment, and Subsequent Wage Gain." American Economic Review, Vol. 66, No. 5, pp. 754-66.

Ely, Richard T. 1886. The Labor Movement in America. New York: T. Y. Crowell.

1938. Ground under Our Feet. New York: Macmillan.

Farber, Henry S. 1978. "Bargaining Theory, Wage Outcomes, and the Occurrence of Strikes: An Econometric Analysis." American Economic Review, Vol. 68, No. 3, pp. 262-71.

Feldstein, Martin. 1974. "Unemployment Compensation: Adverse Incentives and Distributional Anomalies." National Taxjournal, Vol. 27, No. 2, pp. 231-44.

1976. "Temporary Layoffs in the Theory of Unemployment." Journal of Political Economy, Vol. 84, No. 5, pp. 937-57.

Fleisher, Belton. 1970. Labor Economics: Theory and Evidence. Englewood Cliffs, N.J.: Prentice-Hall.

Frank, Robert H. 1985. Choosing the Right Pond: Human Behavior and the Quest for Status. New York: Oxford University Press.

Freeman, Richard. 1972. Labor Economics. Englewood Cliffs, N.J.: Prentice-Hall.

Freeman, Richard, and James Medoff 1984. WhatDo Unions Do? New York: Basic Books.

Friedman, Milton. 1953. Essays in Positive Economics. Chicago: University of Chicago Press.

Goldin, Claudia. 1990. Understanding the Gender Gap. New York: Oxford University Press.

Gordon, David M. 1972. Theories of Poverty and Under- 
employment Lexington, Mass.: Heath, Lexington. Gordon, Donald F. 1974. "A Neo-Classical Theory of Keynesian Unemployment." Economic Inquiry, Vol. 12, No. 4, pp. 431-59.

Griliches, Zvi. 1970. "Notes on the Role of Education in Production Functions and Growth Accounting." In W. Lee Hansen, ed., Education, Income and Human Capital. New York: National Bureau of Economic Research, pp. 71-127.

1977. "Estimating the Returns to Schooling: Some Econometric Problems." Econometrica, Vol. 45, No. 1,pp. 1-22.

Hamermesh, Daniel. 1977. Jobless Pay and theEconomy. Baltimore: Johns Hopkins University Press.

Hamilton, Lee H. 1992. "Economists as Public Policy Advisors." Journal ofEconomic Perspectives, ${ }^{\wedge} o \downarrow$ 6, No. 3, pp. 61-64.

Hanoch, Giora. 1967. "An Economic Analysis of Earnings and Schooling." Journal of Human Resources, Vol. 2, No. 3, pp. 310-29.

Hanushek, Eric A. 1986. "The Economics of Schooling: Production and Efficiency in Public Schools." Journal of Economic Literature, Vol. 24, No. 3, pp. 1141-77.

Harrison, Bennett. 1972. Education, Training, and the Urban Ghetto. Baltimore: Johns Hopkins University Press.

Heckman, James J. 1974. "Shadow Prices, Market Wages, and Labor Supply." Econometrica, Vol. 42, No. 4. pp. 679-94.

1979. "Sample Selection Bias as a Specification Error." Econometrica, Vol. 47, No. 1, pp. 153-62. 1980. "Sample Selection Bias as a Specification Error." In James Smith, ed., Female Labor Supply: Theory and Estimation. Princeton: Princeton University Press, pp. 206-48.

Heckman, James J., and Thomas E. MaCurdy. 1980. "A Life Cycle Model of Female Labor Supply." $R e$ view of Economic Studies, Vol. 47, No. 1, pp. 47-74.

Hicks, John. 1932. The Theory of Wages. London: Macmillan.

1963. TheTheoryofWages,2nded. New York: St Martin's.

Hirsch, Barry. 1991. Labor Unions and the Economic Performance of Firms. Kalamazoo, Mich.: W. E. Upjohn Institute.

Hodgson, Geoffrey M. 1998. "The Approach of Institutional Economics." Journal of Economic Literature, Vol. 36, No. 1, pp. 166-92.

Holmstrom, Bengt, and Paul Milgrom. 1994. "The Firm as Incentive System." American Economic Review, Vol. 84, No. 4, pp. 972-91.

Hutt, W. H. 1939. The Theory of Idle Resources. London: Jonathan Cape.

Katz, Lawrence, and Lawrence Summers. 1989. "Industry Rents: Evidence and Implications." Brookings Papers: Microeconomics, pp. 209-90.

Kaufman, Bruce. 1988. "The Postwar View of Labor Markets and Wage Determination." In Bruce Kaufman, ed., How Labor Markets Work. Lexington, Mass.: Lexington Books, pp. 145-203. 1993. The Origins and Evolution of the Field of Industrial Relations in the United States. Ithaca, N.Y.:
ILR Press.

1994. "The Evolution of Thought on the Competitive Nature of Labor Markets." In Clark Kerr and Paul D. Staudohar, eds., Labor Economics and Industrial Relations. Cambridge, Mass.: Harvard University Press, pp. 145-88.

Kerr, Clark. 1954. "The Balkanization of Labor Markets." In E. Wight Bakke, ed., Labor Mobility and Economic Opportunity. New York: John Wiley \& Sons, pp. $92-110$.

1988. "The Neoclassical Revisionists in Labor Markets (1940-1960)-R.I.P." In Bruce E. Kaufman, ed., How Labor Markets Work. Lexington, Mass.: Lexington Books, pp. 1-46.

1994. "The Social Economics Revisionists: The 'Real World' Study of Labor Markets and Institutions." In Clark Kerr and Paul D. Staudohar, eds., Labor Economics and Industrial Relations. Cambridge, Mass.: Harvard University Press, pp. 66-108.

Knight, Frank. 1921. Risk, Uncertainty and Profit. Boston: Houghton Mifflin.

Krueger, Alan B., and Lawrence H. Summers. 1987. "Reflections on the Inter-Industry Wage Structure." In Kevin Lang and Jonathan S. Leonard, eds., Unemployment and the Structure of Labor Markets. Oxford: Basil Blackwell, pp. 17-47.

1988. "Efficiency Wages and the Inter-industry Wage Structure." Econometrica, Vol. 56, No. 2, pp. 259-93.

Lazear, Edward P. 1979. "Why Is There Mandatory Retirement?" Journal of Political Economy, Vol. 87, No. 6, pp. 1261-64.

1981. "Agency, Earnings Profiles, Productivity, and Hours Restrictions." American Economic Review, Vol. 71, No. 4, pp. 606-20.

1995. Personnel Economics. Cambridge, Mass.: Cambridge University Press.

1998. Personnel Economics for Managers. New York: John Wiley \& Sons.

Lazear, Edward P., and Sherwin Rosen. 1981. "RankOrder Tournaments as Optimum Labor Contracts." Journal of Political Economy, Vol. 89, No. 5, pp. 841-64. Lester, Richard. 1941. Economics of Labor. New York: Macmillan.

1946. "Shortcomings of Marginal Analysis for Wage-Employment Problems." American Economic Review, Vol. 36, No. 1, pp. 63-82.

Lewis, H. Gregg. 1957. "Hours of Work and Hours of Leisure." Proceedings of the Ninth Annual Meeting of the Industrial Relations Research Association (Cleveland, Ohio, Dec. 28-29, 1956), pp. 196-206.

1963. Unions and Relative Wages in the United States. Chicago: University of Chicago Press.

1986. Union Relative Wage Effects: A Survey. Chicago: University of Chicago Press.

Lucas, Jr., Robert E., and Leonard A. Rapping. 1969. "Real Wages, Employment, and Inflation." Journal of Political Economy, Vol. 77, No. 5, pp. 721-54.

Machlup, Fritz. 1946. "Marginal Analysis and Empirical Research." American Economic Review, Vol. 37, No. 4, pp. 519-34.

MaCurdy, Thomas E. 1981. "An Empirical Model of Labor Supply in a Life-Cycle Setting." Journal of 
Political Economy, Vol. 89, No. 6, pp. 1059-85

Marshall, Alfred. 1883 [1925]. "AFair Rate of Wages." In Marshall, Alfred (A. C. Pigou, ed.), Memorials of Alfred Marshall. London: MacMillan.

1890. Principles of Economics. London: Macmillan.

McCall.J.J. 1970. "Economics of Information and Job Search." Quarterly fournal of Economics, Vol. 84, No. 1,pp. 113-26.

McNulty, Paul. 1980. The Origins and Development of Labor Economics. Cambridge, Mass.: MIT Press.

Meyer, Bruce D., W. Kip Viscusi, and David L. Durbin. 1995. "Workers' Compensation and Injury Duration: Evidence from a Natural Experiment." American Economic Review, Vol. 85, No. 3, pp. 322-40.

Millis, Harry, and Royal Montgomery. 1938. Economics of Labor: Labor's Progress and Some Basic Labor Problems. New York: McGraw-Hill.

Mincer, Jacob. 1962a. "Labor Force Participation of Married Women." In Conference of the Universities-National Bureau Committee for Economic Research, Aspects of Labor Economics. Princeton: Princeton University Press, pp. 63-97.

1962b. "On-the-job Training: Costs, Returns, and Some Implications." fournal ofPoliticalEconomy, Vol. 70, No. 5, Part 2, pp. 50-79.

Mincer, Jacob, and Solomon Polachek. 1974. "Family Investment in Human Capital: Earnings of Women." fournal of Political Economy, Vol. 82, No. 2, Part 2, pp. S76-S108.

Mortensen, Dale. 1970a. "Job Search, the Duration of Unemployment, and the Phillips Curve." American Economic Review, Vol. 60, No. 5, pp. 847-62.

1970b. "A Theory of Wage and Employment Dynamics." In Edmund S. Phelps et al., eds., Microeconomic Foundations of Employment and Inflation Theory. New York: W. W. Norton, pp. 167-211.

Neumark, David, and William Wascher. 1997. "The New Jersey-Pennsylvania Minimum Wage Experiment: A Re-Evaluation Using Payroll Records." Unpublished paper, Michigan State University.

Oaxaca, Ronald. 1973. "Male-Female Wage Differentials in Urban Labor Markets." International Economic Review, Vol. 14, No. 3, pp. 693-709.

Oi, Walter. 1962. "Labor as a Quasi-Fixed Factor." fournal of Political Economy, Vol. 70, No. 6, pp. 53855 .

Osterman, Paul. 1975. "An Empirical Study of Labor Market Segmentation." Industrial and Labor Relations Review, Vol. 28, No. 4, pp. 508-23.

, ed. 1984. Internal Labor Markets. Cambridge, Mass.: MIT Press.

Pencavel, John. 1986. "Labor Supply of Men: A Review." In Orley Ashenfelter and Richard Layard, eds., Handbook of Labor Economics. Amsterdam: North-Holland.

Piore, Michael J. 1969. "On-the-job Training in the Dual Labor Market." In Arnold R. Weber et al., eds., Public-Private Manpower Policies. Madison, Wis.: IRRA, pp. 101-32.

Posner, Richard. 1993. "Nobel Laureate: Ronald Coase and Methodology." fournal of Economic Perspectives, Vol. 7, No. 4, pp. 195-210.
President's Commission on an All-Volunteer Armed Force. 1970. Report ofthe President's Commission on an All-Volunteer Armed Force. Washington, D.C.: GPO.

Reder, Melvin W. 1957. Labor in a Growing Economy. New York: John Wiley \& Sons.

1962. "Wage Differentials: Theory and Measurement." In Conference of the Universities-National Bureau Committee for Economic Research, Aspects of Labor Economics. Princeton: Princeton University Press, pp. 257-317.

Rees, Albert. 1973. The Economics of Work and Pay. New York: Harper \& Row.

1976. "H. Gregg Lewis and the Development of Analytical Labor Economics." fournal of Political Economy, Vol. 84, No. 4, pt. 2, pp. S3-S8.

Reynolds, Lloyd. 1948. "Toward a Short-Run Theory of Wages." American Economic Review, Vol. 38, No. 3, pp. 289-308.

1949. Labor Economics and Labor Relations. Englewood Cliffs, N.J.: Prentice-Hall.

1951. The Structure of Labor Markets. New York: Harper.

1970. Labor Economics and Labor Relations. Englewood Cliffs, N.J.: Prentice-Hall.

Robbins, Lionel. 1930. "Note on the Elasticity of Demand for Income in Terms of Effort." Economica, Vol. 10, pp. 123-29.

Robinson, Joan. 1953. On Re-Reading Marx. Cambridge: Students' Bookshop Ltd.

Rosen, Sherwin. 1974. "Hedonic Prices and Implicit Markets." fournal ofPolitical Economy, Vol. 82, No. 1, pp. 34-55.

1985. "Implicit Contracts: A Survey." fournal of Economic Literature, Vol. 23, No. 3, pp. 1144-75.

1986. "Prizes and Incentives in Elimination Tournaments." American Economic Review, Vol. 76, No. 4, pp. 701-15.

Rottenberg, Simon. 1956. "On Choice in Labor Markets." Industrial and Labor Relations Review, Vol. 9, No. 2, pp. 183-99.

Samuelson, Paul A. 1951a. "Economic Theory and Wages." In David McCord Wright, ed., The Impact of the Union. Freeport, N.Y.: Books for Liberty Press, pp. 312-42.

1951b. Economics: An Introductory Analysis. New York: McGraw-Hill.

Schoenberg, Erika, and Paul H.Douglas. 1937. "Studies in the Supply Curve of Labor: The Relation in 1929 between Average Earnings in American Cities and the Proportions Seeking Employment." fournal of Political Economy, Vol. 45, No. 1, pp. 45-79.

Schultz, Theodore. 1963. The Economic Value of Education. New York: Columbia University Press.

Sjaastad, Larry A. 1962. "The Costs and Returns of Human Migration." fournal ofPoliticalEconomy, Vol. 70, No. 5, pt. 2, pp. 80-93.

Slichter, Sumner. 1950. "Notes on the Structure of Wages." Review of Economics and Statistics, Vol. 32, No. 1, pp. 80-91.

Smith, Robert. 1979. "Compensating Wage Differentials and Public Policy: A Review." Industrial and Labor Relations Review, Vol. 32, No. 3, pp. 339-52.

Solow, Robert. 1990. The Labor Market as a Social 
Institution. Cambridge, Mass.: Basil Blackwell. Stigler, George. 1961. "The Economics of Information." Journal of Political Economy, Vol. 69, No. 3, pp. 213-25.

1962. "Information in the Labor Market." Journal of Political Economy, Vol. 70, No. 5, Part 2, pp. 94-105.

1969. "Does Economics Have a Useful Past?" History of Political Economy, Vol. 1, No. 2, pp. 217-30. Thurow, Lester C. 1975. Generating Inequality. New York: Basic Books.

Topel, Robert H. 1983. "On Layoffs and Unemployment Insurance." American Economic Review,Vol. 73, No. 4, pp. 541-59.

Tracy, Joseph S. 1987. "An Empirical Test of an Asymmetric Information Model of Strikes." Journal of Labor Economics, Vol. 5, No. 2, pp. 149-73.

U.S. President. Various. Economic Report of the President. Washington, D.C.: GPO.

Viscusi.W.Kip. 1993. "The Value of Risks to Life and Health." Journal of Economic Literature, Vol 31, No. 4, pp. 1912-46.

Willis, Robert J., and Sherwin Rosen. 1979. "Education and Self-Selection." Journal of Political Economy, Vol. 87, No. 5, Part 2, pp. S7-S36.

Yellen, Janet L. 1984. "Efficiency Wage Models of Unemployment. " American Economic Review, Vol. 74, No. 2, pp. 200-205.

Yoder, Dale. 1933. Labor Economics and Labor Problems. New York: McGraw Hill.

Yonay, Yuval P. 1998. The Struggle over the Soul of Economics. Princeton: Princeton University Press. 
Copyright of Industrial \& Labor Relations Review is the property of Cornell University. The copyright in an individual article may be maintained by the author in certain cases. Content may not be copied or emailed to multiple sites or posted to a listserv without the copyright holder's express written permission. However, users may print, download, or email articles for individual use. 